\title{
Silver and gold nanoparticles synthesized from Streptomyces sp. isolated from acid forest soil with special reference to its antibacterial activity against pathogens
}

\author{
M. Składanowski ${ }^{1} \cdot$ M. Wypij ${ }^{1}$ - D. Laskowski ${ }^{1}$. \\ P. Golińska ${ }^{1}$ H. Dahm ${ }^{1} \cdot$ M. Rai ${ }^{2}$
}

Received: 1 June 2016/Published online: 18 July 2016

(c) The Author(s) 2016. This article is published with open access at Springerlink.com

\begin{abstract}
Biological systems such as bacteria, fungi or plants for synthesis of noble nanoparticles (NPs) are easy, inexpensive and eco-friendly. Obtained bioparticles due to its physico-chemical nature possess biologically active properties such as antimicrobial activity. In this study, the biological synthesis of silver ( $\mathrm{Ag}$ ) and gold (Au) nanoparticles using Streptomyces sp. strain NH21 isolated from acidic soil and its antibacterial activity against bacteria is presented. The physico-chemical properties of obtained particles were characterized. UV-Vis showed broad peak at 404 and $424 \mathrm{~nm}$ for AgNPs and $564 \mathrm{~nm}$ for AuNPs. Transmission electron microscopy studies showed small sized nanoparticles of $44 \mathrm{~nm}$ for supernatant and $8.4 \mathrm{~nm}$ for biomass synthesized AgNPs, and $10 \mathrm{~nm}$ for supernatant synthesized AuNPs, which was confirmed by nanoparticle tracking analyses. Fourier transform infrared spectroscopy revealed the presence of capping agents over metal-NPs. The negative Zeta potential values of metal-NPs indicated stability of biosynthesized particles. In vitro antibacterial activity and minimal inhibitory concentration of NPs was assessed against Gram-positive and Gram-negative bacteria. Unlike to gold-NPs, silver-NPs showed reliable antibacterial activity. Atomic force microscopy analysis recorded changes in cell morphology of tested bacterial strains after treatment with nanoparticles.
\end{abstract}

Keywords Antibacterial activity · Biogenic synthesis · Silver nanoparticles · Gold nanoparticles

P. Golińska

golinska@umk.pl

1 Department of Microbiology, Nicolaus Copernicus University, Lwowska 1, Toruń, Poland

2 Nanobiotechnology Laboratory, Department of Biotechnology, S.G.B. Amravati University, Amravati, Maharashtra, India 


\section{Introduction}

The rise of antibiotic-resistance in pathogenic microorganisms represents one of the most serious problems facing humankind. Antibiotic resistance is rapidly depleting the limited range of antibiotic therapies which has led to a call from academics and clinicians that action needs to be taken to replace the current generation of antibiotics. There is a real risk in the near future that there will be few or no antibiotic for drug resistant microorganisms, particularly multidrug resistant (MDR) Gram-negative pathogens [1]. Consequently, developing new or better antibiotics and non-antibiotic compounds will have a clear and positive impact on global public health.

Nanotechnology provides an excellence platform to modify and develop the properties of metals by converting them into their nanoform (nanoparticles) which has applications in numerous fields like diagnostic, drug delivery, antimicrobial agents and treatment of various diseases [2]. Several physical and chemical methods have been developed to produce silver and gold nanoparticles. Synthetic techniques based on the reduction of metal ions with sodium citrate or sodium borohydride, followed by surface modification of the produced particles with suitable capping ligands and organic solvent raised environmental concerns because of the toxic compounds used in the process. Synthetic methods results in mixed-shape of nanoparticles (NPs) that require expensive and low-yield purification procedure. These limitations invite new eco-friendly methodology for production of nanocrystals with desired shape. Biosynthesis method have emerged as a simple, non-toxic and environmental friendly. The nanoparticles synthesis by living organism came with several challenges such a reducing the time of synthesis and better understanding of their size and shape.

Biological resources available in nature including plants, fungi, yeast, actinomycetes and bacteria can be employed for synthesis of NPs, including silver and gold nanoparticles, which exhibited different biological activity [3-9].

Nevertheless, the number of prokaryotic organisms (bacteria and actinomycetes) have been evaluated for their ability to produce NPs, the synthesis is limited and needs to be extended. Although actinomycetes are well exploited for antibiotics and other high value metabolites, they are less studied in terms of nanoparticles. Free amine groups and cysteine residues of the actinomycete proteins bind to silver or gold NPs and stabilize synthesized nanoparticles. Proteins involved in reduction of silver or chloroauric ions and cap the metal NPs may belong to the enzymes released from cells. Different proteins may occur as a capping and stabilizing agent on the surface of metal nanoparticles $[10,11]$.

Actinomycetes secret four specific proteins of molecular masses between 10 and $80 \mathrm{kDa}$. The nature of different proteins and their strength of interaction may vary with different nanorystals which may lead to the formation of complex morphology and size [11].

Various biological agents react differently with metal ions leading to the formation of nanoparticles. Many microorganisms produce metal nanoparticles either intra- or extra cellularly. In case of actinomycetes, the reduction of metal ions 
take place on the surface of mycelia along with cytoplasmatic membrane resulting in the formation of nanoparticles [12].

The intracellular method of metal nanoparticle synthesis involves special ion transportation in the microbial cell. The cell wall of microorganism plays an important role. The mechanism involves electrostatic interaction of the positive charge metal ions with negatively charged cell wall. Mechanism of synthesis of silver nanoparticles by microorganism is found to be nitrate reductase mediated [13].

The enzymes involved in gold synthesis are not exactly known. Recently, involvement of phenol oxidase in this process have been reported [14].

Antimicrobial potential of metal nanoparticles have been evaluated against a wide range of bacterial, including MDR and fungal pathogens $[15,16]$. The unusual physiochemical properties of nanoparticles are attributed to their small size $(<10 \mathrm{~nm})$, surface structure, reactive groups and coatings [17]. AgNPs are one of the most widely used nanoparticles and notably serving as an antimicrobial agent for medical applications [18-22].

The antimicrobial toxicity of AgNPs may be explained by their interaction with microbes involving silver ion release and particle cellular internalization [23], also they have emerged as novel agents because of their high surface area to volume ratio and the unique chemical and physical properties. AgNPs interact with many compounds of bacterial cell: (1) peptidoglycan of cell wall, (2) cytoplasmatic membrane, where chemical and physical properties are modified causing change in osmolality, permeability and electron transport, (3) ribosomal DNA, molecular sites of phosphorus and sulfur present in proteins [24]. Compared with other metals silver exhibits higher toxicity to microorganism while lower toxicity to mammalian cells [25]. AgNPs preferable attack the respiratory chain, cell division and finally leading to cell death [19]. Gold nanoparticles, in general, are preferred over other inorganic nanoparticles for biomedical applications due to its excellent biocompatibility with human cells. However, the toxicity caused by AuNPs is a great topic of debate due to the ambiguity in the studies undertaken to determine its harmful effects. Some studies reported non-toxic whereas others toxic effect of AuNPs to human cells [26].

Because of stability of oxidation resistance and biocompatibility gold nanoparticles found wide application in electronics, catalysis, chemical testing and imaging, drug delivery and biological labeling [27]. Biocompatible AuNPs were found to be efficient agent in cancer therapy [28]. Williams et al. [29] reported that AuNPs used alone did not show antibacterial activity. However, AuNPs conjugated with antibiotics were found to improve antibiotic activity and delivery. The improvement efficacy of antibacterial antibiotics conjugated with AuNPs was evaluated against various bacterial strains [30]. 


\section{Materials and Methods}

\section{Actinobacteria Strain}

The Streptomyces sp. NH21 strain was isolated from humic layer of acidic pine forest soil. The sample site was located on north slope of inland dune in Czerniewice forest district $\left(52^{\circ} 55^{\prime} 37^{\prime \prime} \mathrm{N}, 18^{\circ} 42^{\prime} 11^{\prime \prime} \mathrm{E}\right)$ near Torun, Poland. The humic layer, approximately $2 \mathrm{~cm}$ wide, contained an amorphous mass of decomposed needles, humic material and other organic matter. The mean $\mathrm{pH}$ value of soil was estimated at $3.65( \pm 1.2)$. The strain was maintained on Starch Casein Agar slopes (SCA, Küster and Williams, 1964 [31]) at $27^{\circ} \mathrm{C}$ and as a spore suspension in $20 \%$ glycerol (v/v) at $-80{ }^{\circ} \mathrm{C}$.

\section{Identification of Streptomyces sp. NH21 Strain}

Biomass for the molecular systematic study was prepared by cultivating the isolate in shake flask of yeast extract-malt extract broth $(\mathrm{pH} \mathrm{5.5)}$ at 150 revolutions per minute at $27{ }^{\circ} \mathrm{C}$ for 2 weeks. Cells were harvested by centrifugation and washed three times with sterile distilled water. Genomic DNA was extracted from cells using a GenElute ${ }^{\mathrm{TM}}$ Bacterial Genomic Kit (Sigma), according to the instructions of the manufacturer, previously treated with lysozyme at $45 \mathrm{mg} \mathrm{mL}^{-1}$ and incubated overnight at $37{ }^{\circ} \mathrm{C}$. The $16 \mathrm{~S}$ rRNA was amplified by using universal primers p27f and p1525r [32]. PCR-mediated amplification of the $16 \mathrm{~S}$ rRNA gene of the isolate were carried out as described by Golinska et al. [33]. The PCR product was purified with GenEluate ${ }^{\mathrm{TM}}$ PCR Clean-Up Kit (Sigma) and sent to Institute of Biochemistry and Biophysics Polish Academy of Sciences for sequencing. The closest phylogenetic neighbors based on 16S rRNA gene similarities were found using the EzTaxon server [34]. The phylogenetic analysis were performed according to methods described previously by Golinska et al. [33].

\section{Biosynthesis of Nanoparticles Using Supernatant and Biomass of Actinobacteria Culture}

Actinobacterial Streptomyces sp. NH21 strain was inoculated in flask with ISP2 broth and incubated in rotary shaker at $27{ }^{\circ} \mathrm{C}$ for 14 days. After incubation strain was centrifuged $6000 \times g$ for $15 \mathrm{~min}$ at $4{ }^{\circ} \mathrm{C}$. The cell free supernatant was collected and combined with $3 \mathrm{mM}$ silver nitrate $\left(\mathrm{AgNO}_{3}\right)$ for silver nanoparticles synthesis or $3 \mathrm{mM}$ chloroauric acid $\left(\mathrm{HAuCl}_{4}\right)$ for gold nanoparticles synthesis, both 1:1 (v/v). The mixture was kept in shaker $\left(130 \mathrm{rev} / \mathrm{min}, 27^{\circ} \mathrm{C}\right)$ in darkness up to $72 \mathrm{~h}$. The biomass obtained from centrifugation was washed three times with sterile distillated water, then suspended in water and kept for next $48 \mathrm{~h}$ for starvation. The biomass was then centrifuged $6000 \times g$ for $15 \mathrm{~min}$. The supernatant was filtered by sterile $0.22 \mu \mathrm{m}$ filter, challenged with relevant reagent $\left(\mathrm{AgNO}_{3}\right.$ or $\left.\mathrm{HAuCl}_{4}\right)$ and incubated, as described previously. During the incubation period flasks were observed for color 
change from yellow to dark-brown for AgNPs and from yellow to purple for AuNPs formation.

\section{Silver and Gold Nanoparticles Analyses}

\section{UV-Visible Spectroscopy Studies}

The presence of synthesized nanostructures were confirmed by UV-Vis spectroscopy analysis using spectrophotometer (NanoDrop 2000, Thermo Scientific, USA) at wavelength range of $200-700 \mathrm{~nm}$.

\section{Transmission Electron Microscopy (TEM) Studies}

TEM analysis of silver and gold nanoparticles were carried out using FEI Europe TEM microscope, model Tecnai F20 X-Twin at $100 \mathrm{kV}$ coupled with the energy dispersive X-ray (EDX), selected area electron diffraction pattern (SAED) and fast Fourier transform (FFT) analysis (XFlash 4010 Bruker AXS). The sample containing dried nanoparticles was diluted in sterile double distilled water, applied on carbon-coated cooper TEM grids $(400 \mu \mathrm{m}$ mesh size) and dried in room temperature. The acquired data were evaluated by Statistica Software (StatSoft, USA) using the variability plot of average methods.

\section{XRD Spectroscopy Analysis}

The fingerprint characterization of crystalline metallic silver and gold nanoparticles and the determination of their structure were performed by X-ray analysis diffraction (XRD). The AgNPs sample (powder) was deposited into the sample holder and pressed to get a smooth plane surface. The diffraction pattern was recorded over a $2 \theta$ range of $5^{\circ}-120^{\circ}$ by X-ray diffractometer (X'Pert Pro Analytical Phillips, Lelyweg, Netherlands) equipped with Ni filter and $\mathrm{CuK} \alpha(\lambda=1.54056 \AA)$ radiation source. The obtained diffractogram was compared to the standard database of the International Centre for Diffraction Data (ICDD).

\section{Fourier Transform Infrared (FT-IR) Spectroscopy Studies}

The characterization of functional groups on the surface of AgNPs and AuNPs was investigated by FT-IR spectrometer Spectrum 2000 (Perkin-Elmer). The sample was prepared by dispersing the nanoparticles in a matrix of dry $\mathrm{KBr}$ compressed to form a disc. The spectrum was scanned in the range of $4000-500 \mathrm{~cm}^{-1}$ at a resolution of $4 \mathrm{~cm}^{-1}$.

\section{NTA Studies}

The size and distribution of size of synthesized nanoparticles were measured using nanoparticle tracking analysis (NTA) system by NanoSight Ltd., (Amesbury, UK). 
Samples were diluted in $5 \mu \mathrm{L}$ of nuclease-free water and injected into the chamber. The size of nanoparticles was then measured.

\section{Zeta Potential Analysis}

The zeta potential was measured to determine the stability of silver and gold nanoparticles using the Zetasizer Nano ZS 90 (Malvern Instrument Ltd., UK). $25 \mu \mathrm{L}$ of nanoparticle samples were diluted 10 times with water and sonicated for $15 \mathrm{~min}$ at $20 \mathrm{~Hz}$. Then mixture was filtered with of $0.22 \mu \mathrm{m}$ filter and used for zeta potential measurement. The dilution of AgNPs or AuNPs were carried out to avoid the aggregation of nanoparticles. Measurements were obtained in the range of -200 to $+200 \mathrm{mV}$.

\section{Determination of Minimal Inhibitory Concentration (MIC) and Minimal Bactericidal Concentration (MBC) of Silver and Gold Nanoparticles}

The MIC and MBC studies of biosynthesized nanoparticles against pathogenic organisms such as Salmonella infantis (strain obtained from Sanitary-Epidemiological Station in Torun, Poland) Proteus mirabilis (strain obtained from the collection of the Collegium Medicum, Nicolaus Copernicus University in Poland), Bacillus subtilis (ATTC6633), Staphylococcus aureus (ATTC6338), Klebsiella pneumoniae (ATTC700603), Pseudomonas aeruginosa (ATTC10145) and Escherichia coli (ATTC8739). Studies were performed in the 96 microtiter plates. The synthesized AgNPs and AuNPs were screened for MIC by microtiter broth dilution method in triplicates. Trypticase soy broth (TSB) was used as diluents for bacterial strains. The final concentration of bacterial cells in each well was $1 \times 10^{6} \mathrm{CFU} / \mathrm{mL}$, and various concentrations $(1.25-200 \mu \mathrm{g} / \mathrm{mL})$ of AgNPs or AuNPs were used. The positive and negative controls were also maintained. After incubation for $24 \mathrm{~h}$ at $37{ }^{\circ} \mathrm{C}$ the microtiter plates were read at $450 \mathrm{~nm}$ using BIOLOG multimode reader after incubation to determine the minimum inhibitory concentration values. The MIC is expressed as the lowest concentration of compound, which inhibited the bacterial growth when compared with control. Moreover, the minimum bactericidal concentrations (MBC) expressed as the lowest concentration of nanoparticles that kills $\geq 90 \%$ of bacterial cells were estimated.

\section{Atomic Force Microscopy (AFM)}

The alterations in the bacterial cell surface caused by silver or gold nanoparticles were confirmed by Agilent 5500 atomic force microscopy (Keysight Technologies). Ten microliters of suspension containing bacterial cells with nanoparticles cultured in TSB medium were applied on a gelatin-coated glass surface [35]. The samples were incubated for the $20 \mathrm{~min}$ in room temperature, gently rinsed with deionized water and nitrogen dried before imaging. Sample were imaged in contact mode in air, using MLCT silicon nitride cantilevers with a spring constant of $0,01 \mathrm{~N} / \mathrm{m}$ and a nominal tip apex radius of $20 \mathrm{~nm}$. Topography and deflection images were obtained 
at a scan rate $0,5 \mathrm{ln} / \mathrm{s}$ at a resolution of 512 pixel per line. The data were analyzed with Gwyddion 2.41 software [36].

\section{Data Analysis}

Antibacterial activity data were analyzed by using $t$ test (for AgNPs concentration $10 \mu \mathrm{g} / \mathrm{mL}$ ) and Kruskal-Wallis One Way Analysis of Variance on ranks (for AgNPs concentration $5 \mu \mathrm{g} / \mathrm{mL}$ ). In all analyses, a probability level of $\mathrm{P}<0.05$ was used for the significance of differences between values. The obtained data were evaluated by Statistica Software (StatSoft, USA).

\section{Results}

\section{Identification of Actinobacteria Strain}

Near complete 16S rRNA gene sequence (1406 nucleotides [nt]) of the isolate Streptomyces sp. NH21 was determined. Strain NH21 was found to be loosely associated with the type strain of Streptomyces yanglinesis $1307^{\mathrm{T}}$ in the neighbourjoining tree though this relationship were supported by $97 \%$ bootstrap value and by all of the tree-making methods. The two strains shared $99.2 \% 16 \mathrm{~S}$ rRNA gene sequence similarity, a value which corresponded to $11 \mathrm{nt}$ differences at 1404 locations. Levels of $16 \mathrm{~S}$ rRNA gene sequence similarity between strain NH21 and the type strains of other member of the clade were $98.6 \%$ with Streptomyces paucisporeus $1413^{\mathrm{T}}$, $97.8 \%$ with Streptomyces staurosporininus $\mathrm{BK} 179^{\mathrm{T}}$ and Streptomyces cocklensis $\mathrm{BK} 168^{\mathrm{T}}$, a values that correspond to 20,30 and $31 \mathrm{nt}$ differences over 1406 and 1393 locations, respectively (Fig. 1).

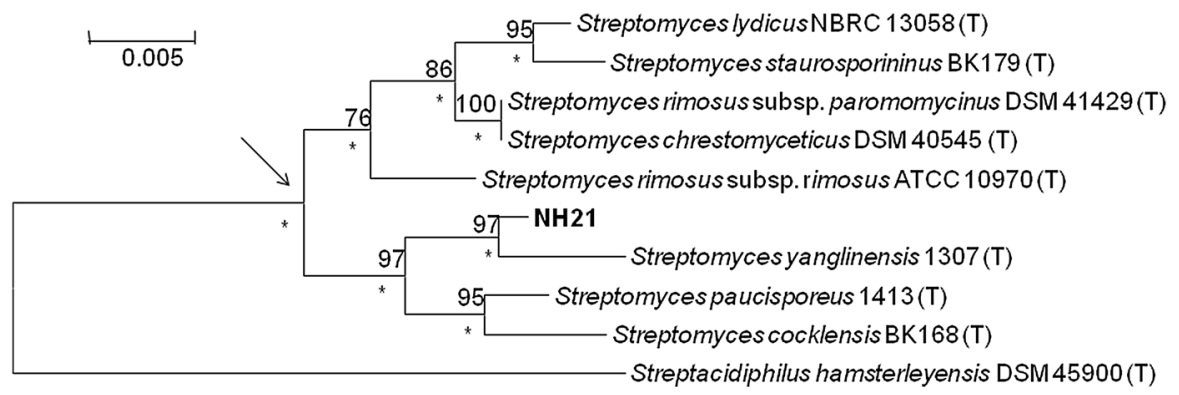

Fig. 1 Neighbour-joining tree based on nearly complete 16S rRNA gene sequences (1403-1485 nucleotides) showing relationship between strain NH21 and the type strains of Streptomyces species. Asteriks indicate branches of the tree that were also found using maximum-likelihood and maximumparsimony tree making algorithms. Numbers at the nodes indicate the percentage bootstrap values based on 1000 re-sampled datasets. Only values above $50 \%$ are given. $T$ type strain. Bar 0.005 substitutions per nucleotide position. The root position of the tree was determined by using Streptacidiphilus hamsterleyensis DSM $45900^{\mathrm{T}}$ 

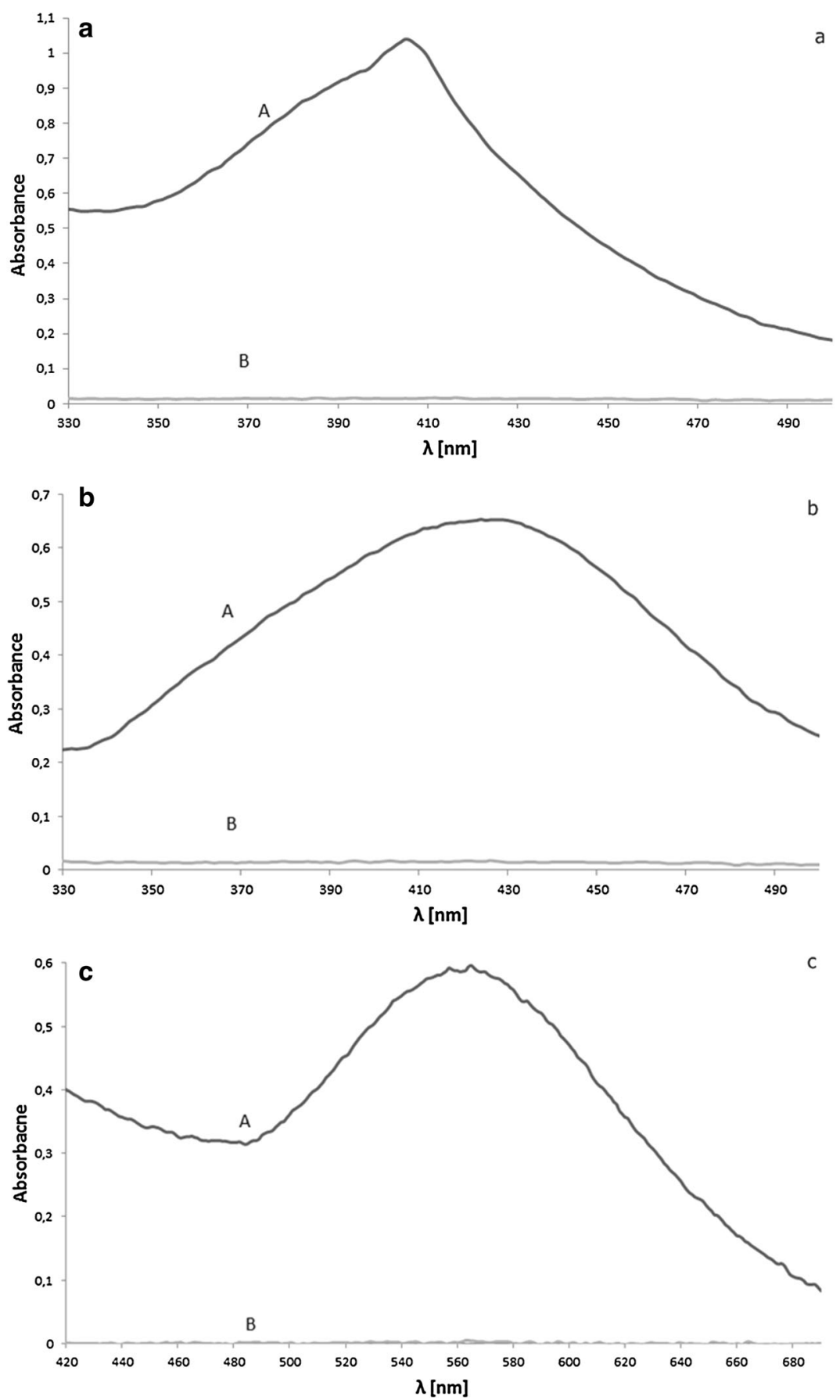

Fig. 2 UV-Vis spectrum of silver nanoparticles from supernatant (a), of silver nanoparticles from biomass (b) and of gold nanoparticles (c). $A$ experimental, $B$ control 


\section{Characterization of Silver and Gold Nanoparticles}

After incubation time the color change of test samples were noticed when compared with controls. Flasks containing silver nanoparticles changed color from yellow to dark brown/herbal, while containing gold nanoparticles changed color from yellow to purple. In turn to biomass, the presence of AuNPs was only recorded in culture supernatant.

\section{UV-Vis Spectrophotometer Analysis}

Presence of metal nanoparticles was confirmed using UV-Vis spectrophotometer (Fig. 2). Silver nanoparticles shown a peak at wavelength of 404, $424 \mathrm{~nm}$ and gold nanoparticles of $564 \mathrm{~nm}$. Observation of peaks by UV-Vis spectrophotometer analysis is well documented for various metal nanoparticles with a size ranging from 2 to $100 \mathrm{~nm}$.

\section{TEM Analysis}

Each of synthesized metal nanoparticles was analyzed by TEM which revealed presence of spherical and oval silver nanoparticles, and sizes $44 \mathrm{~nm}( \pm 9)$ for supernatant and $8.4 \mathrm{~nm}( \pm 12)$ for biomass synthesized particles. The gold nanoparticle were mostly spherical in shape and $10 \mathrm{~nm}( \pm 14)$ in size (Fig. 3). The selected area electron diffraction (SAED) analysis revealed that the distances between atomic planes, calculated from FFT, were 0.232 for supernatant AgNPs, $0.234 \mathrm{~nm}$ for biomass obtained AgNPs nm, and $0.204 \mathrm{~nm}$ for AuNPs, which are characteristic for metallic silver and gold nanoparticles (Fig. 3).

The EDX analysis and mapping of elements revealed strong signal of $\mathrm{Ag}$ and $\mathrm{Au}$ with high weight percentage of both metals in analyzed samples. The wt $\%$ mass of $\mathrm{Ag}$ was recorded at 82.8 and $98.2 \%$ for supernantant and biomass synthesized AgNPs, respectively. The wt \% mass of Au in AuNPs was found to be $84.8 \%$. The lowest signal from $\mathrm{C}$ and $\mathrm{O}$ were also noted (Fig. 4).
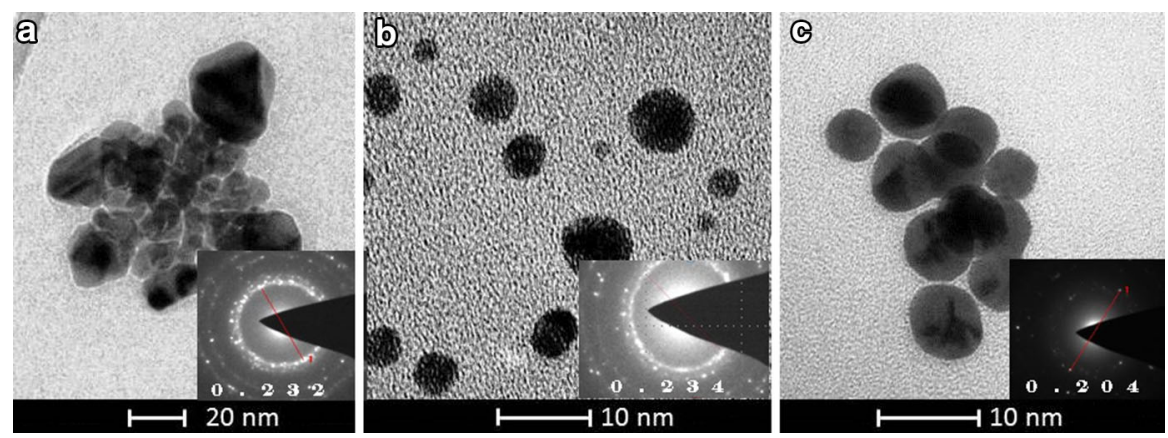

Fig. 3 Transmision electron microscopy (TEM) micrograph and SAED pattern of silver nanoparticles from supernatant (a), of silver nanoparticles from biomass (b) and of gold nanoparticles (c) 

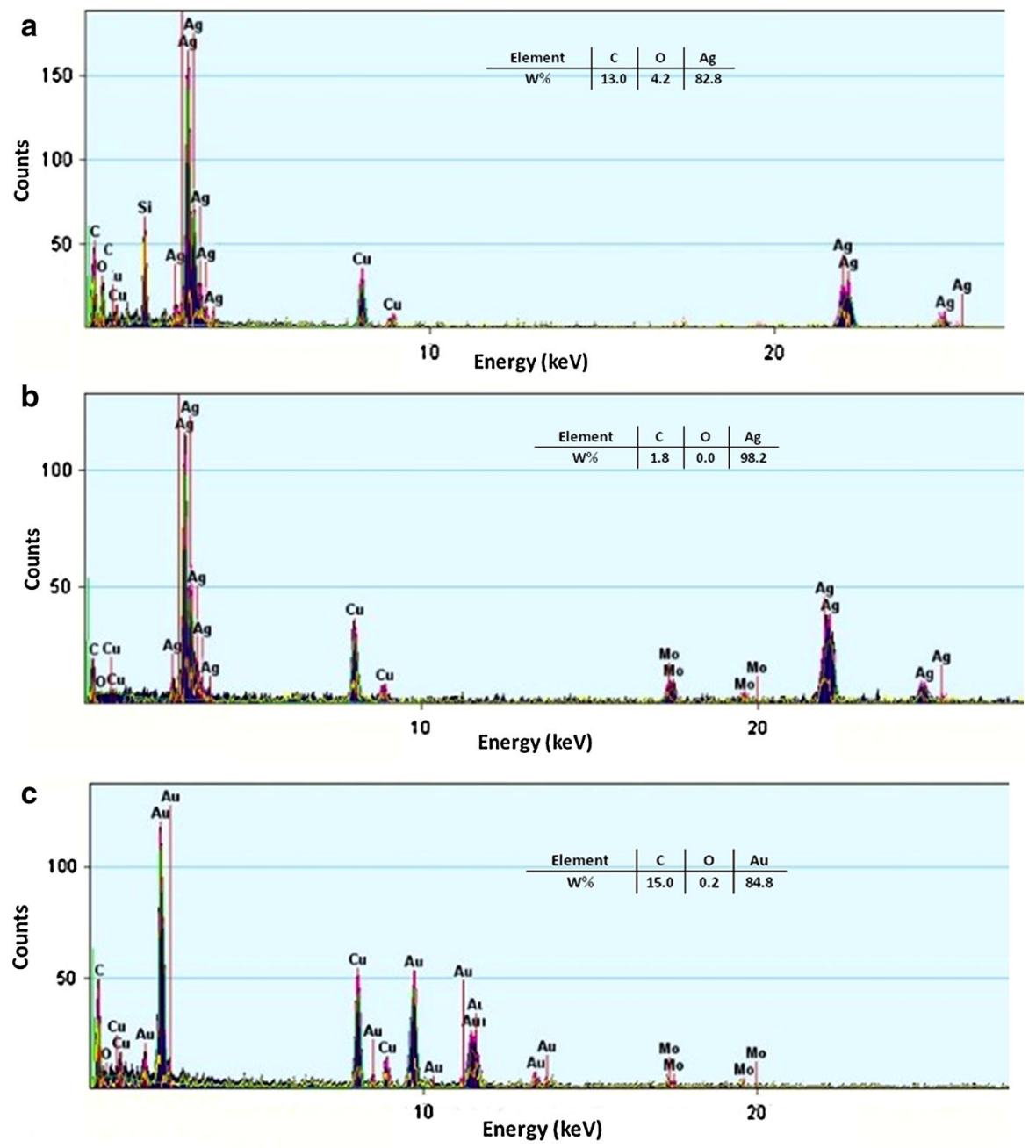

Fig. 4 EDX spectra of a biosynthesized silver nanoparticles from supernatant (a), of silver nanoparticles from biomass (b) and of gold nanoparticles (c) wt\% mass percentage of analyzed element

\section{X-Ray Diffraction (XRD) Analysis}

The typical XRD patterns of silver and gold nanoparticles biosynthesized from NH28 actinobacterial strain were observed (Fig. 5a-c). Results confirmed that silver and gold bionanoparticles were in form of nanocrystals. The characteristic diffraction peaks for AgNPs formed in supernatant were found at $2 \theta=38.1^{\circ}$, $44.6^{\circ}, 64.6^{\circ}, 77.5^{\circ}, 81.5^{\circ}$ and $115.0^{\circ}$ (Fig. 5a), and in biomass were present at $2 \theta=38.1^{\circ}, 44.5^{\circ}, 64.6^{\circ}, 77.6^{\circ}$ and $81.7^{\circ}$ (Fig. 5b). The typical peaks of AuNPs were located at $2 \theta=38.1^{\circ}, 44.3^{\circ}, 64.6^{\circ}, 77.6^{\circ}, 81.7^{\circ}, 98.2^{\circ}, 111.0^{\circ}$ and $115.2^{\circ}$ (Fig. 5c). 

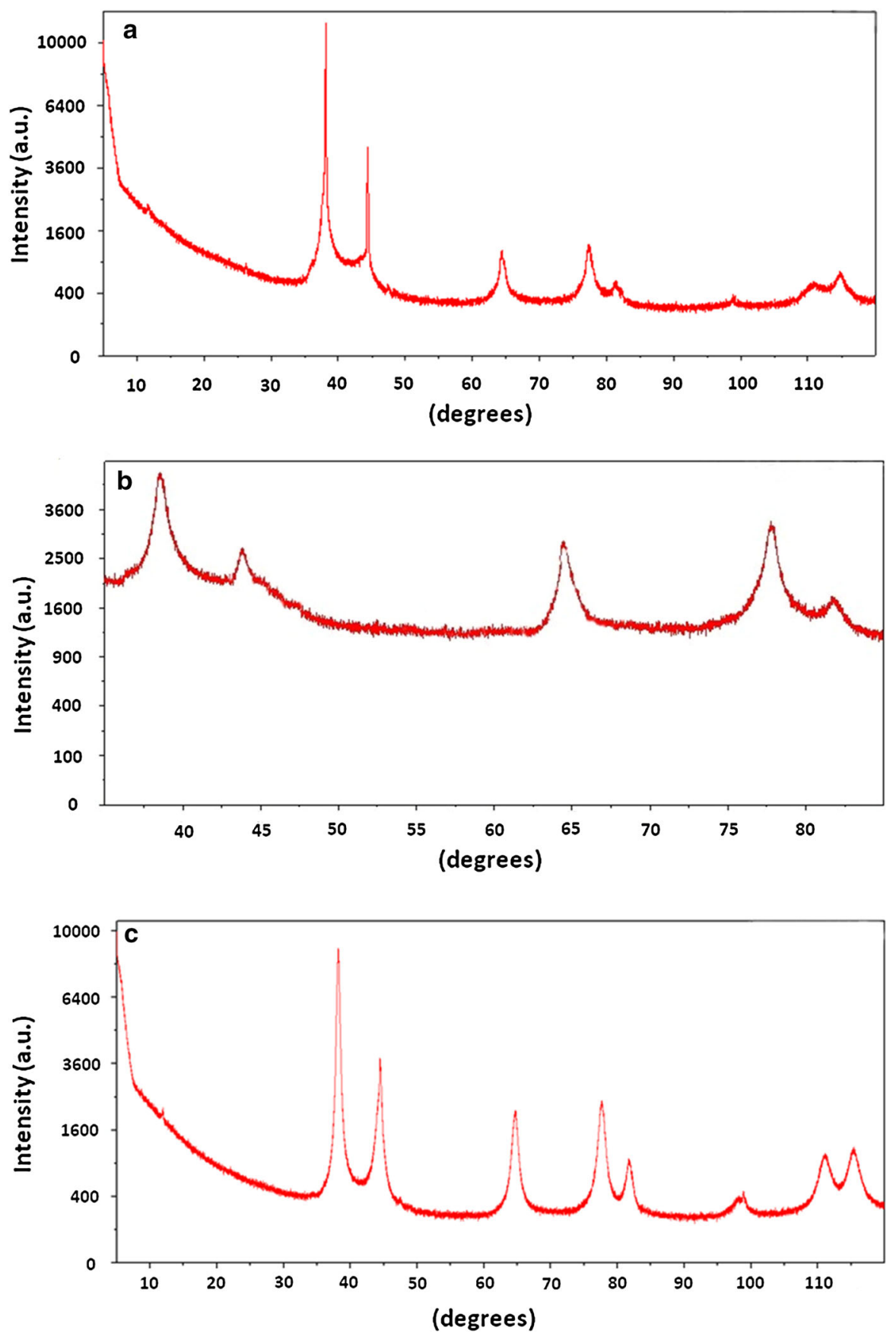

Fig. 5 X-ray analysis diffraction (XRD) pattern of silver nanoparticles from supernatant (a), of silver nanoparticles from biomass (b) and of gold nanoparticles (c) 


\section{FT-IR Spectroscopy Analysis}

FTIR analysis of synthesized silver nanoparticles using of filtrate biomass after starvation, revealed presence of seven bands $(3447,2927,1658,1591,1384,1034$ and $875 \mathrm{~cm}^{-1}$ ), and from cell free culture presented peaks at 3447, 2925, 1611, 1444, 1384, 1038 and $875 \mathrm{~cm}^{-1}$. Gold nanoparticles analysis showed a bands at 3446, 2926, 1608, 1384, 1041 and $875 \mathrm{~cm}^{-1}$ (Fig. 6).

\section{NTA Analysis}

The average size of synthesized silver and gold nanoparticles was $51 \mathrm{~nm}( \pm 46 \mathrm{~nm})$ for supernatant synthesized, $27 \mathrm{~nm}( \pm 25 \mathrm{~nm})$ for biomass and $34 \mathrm{~nm}( \pm 21 \mathrm{~nm})$ for gold nanoparticles. The concentration of silver and gold nanoparticles were of $0.18 \times 10^{8}, 0.31 \times 10^{8}$ and $0.22 \times 10^{8}$ particles per mL, respectively (Fig. 7).

\section{Zeta Potential Analysis}

The zeta potentials of AgNPs and AuNPs were noticed to be $-9.95 \mathrm{mV},-19.4 \mathrm{mV}$ and $-14.5 \mathrm{mV}$, respectively. Results indicated monodispersity and stability of the synthesized nanoparticles due to the electrostatic repulsion between particles in the solution (Fig. 8).

\section{Minimum Inhibitory and Minimum Bactericidal Concentration Assay}

Results of MIC and MBC silver nanoparticles synthesized from supernatant and biomass of NH21 strain can be seen in Table 1. The activity of nanoparticles (both
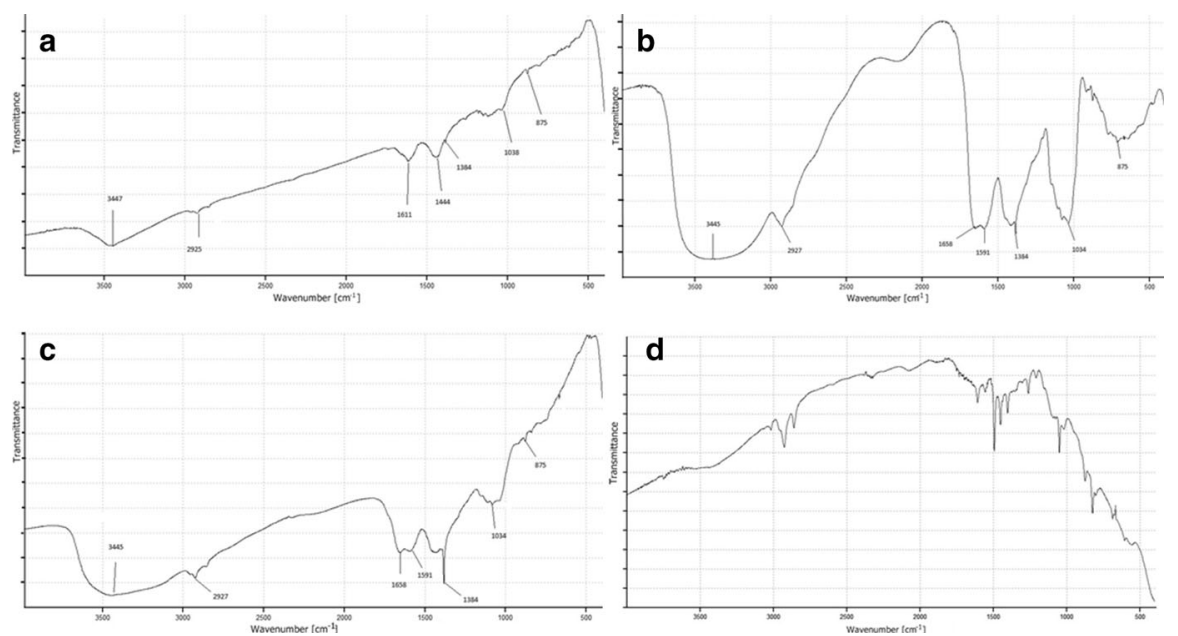

Fig. 6 FT-IR spectrum analysis of silver nanoparticles from supernatant (a), of silver nanoparticles from biomass (b) and of gold nanoparticles (c), control (d) 


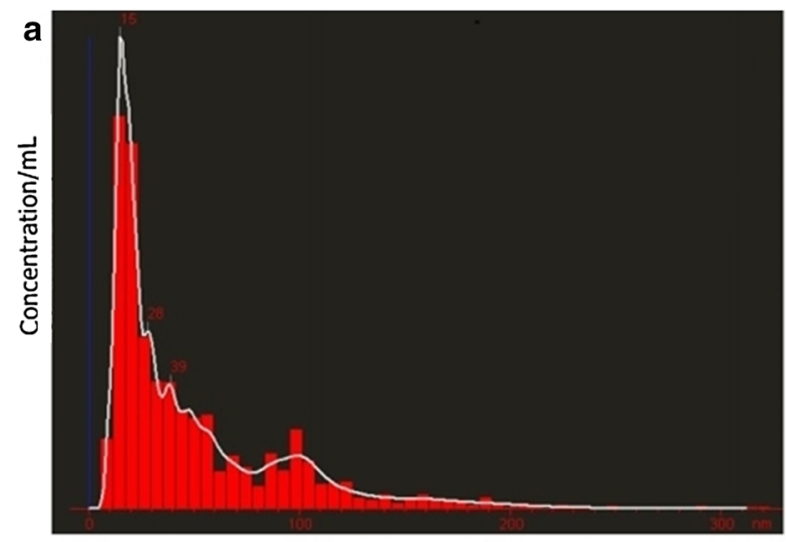

Wavelenght $[\mathrm{nm}]$
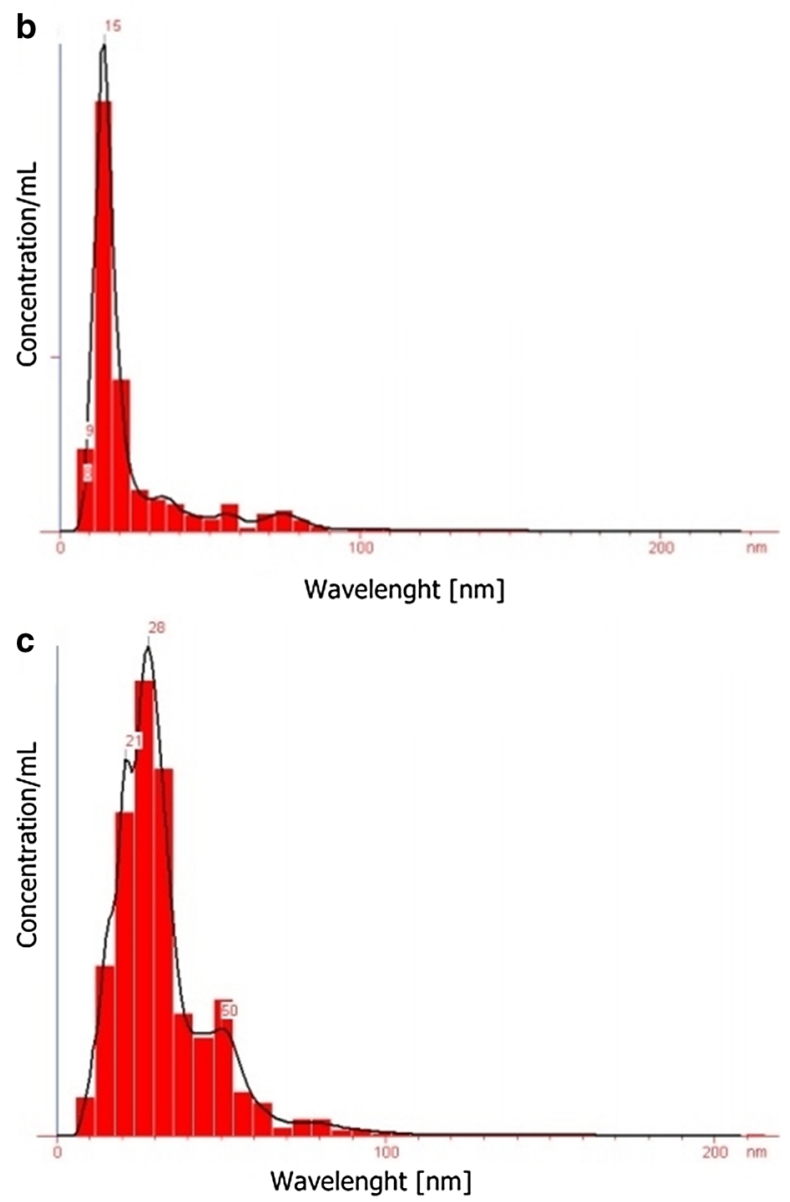

Fig. 7 NTA analysis of silver nanoparticles from supernatant (a), of silver nanoparticles from biomass (b) and of gold nanoparticles (c) 

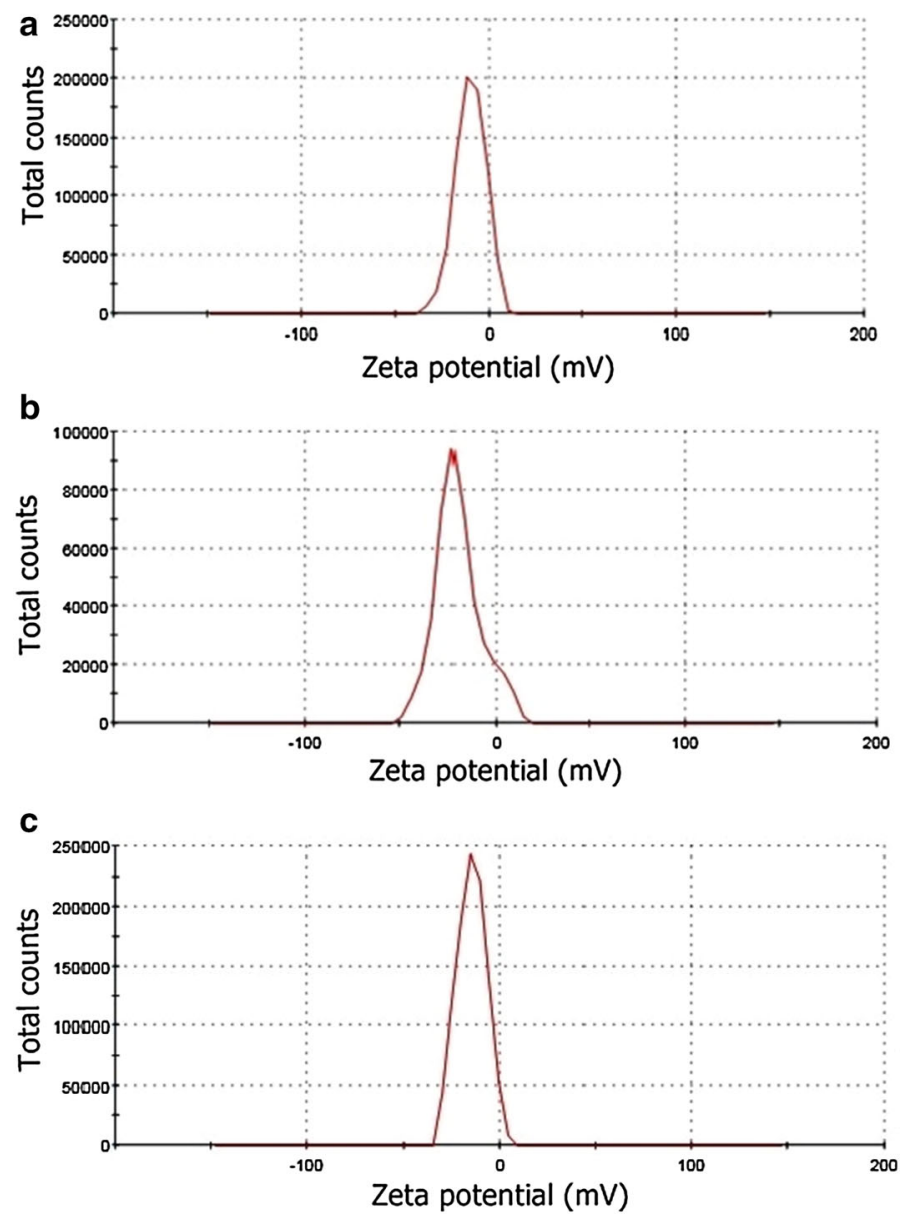

Fig. 8 Zeta potential distribution of silver nanoparticles from supernatant (a), of silver nanoparticles from biomass (b) and of gold nanoparticles (c)

AgNPs and AuNPs) obtained from culture supernatant against clinical pathogens was not noticed. Silver nanoparticles obtained from cell filtrate of starved biomass were effective against clinical bacteria. The MIC values of AgNPs against E. coli was found to be $2.5 \mu \mathrm{g} / \mathrm{mL}$, against $K$. pneumoniae, $P$. mirabilis and $S$. infantis $5 \mu \mathrm{g} / \mathrm{mL}$ and agianst $P$. aeruginosa and B. subtilis $10 \mu \mathrm{g} / \mathrm{mL}$. Minimum bactericidal concentrations (MBC) have been demonstrated for two clinical strains- $P$. aeruginosa and B. subtilis in concentrations of 140 and $170 \mu \mathrm{g} / \mathrm{mL}$, respectively.

\section{AFM Analysis}

AFM images of B. subtilis, E. coli and P. aeruginosa cells before and after nanoparticles exposure are shown in Fig. 9. The samples treated with AgNPs for 
Table 1 Minimum inhibitory and bactericidal concentrations $(\mu \mathrm{g} / \mathrm{mL})$ of AgNPs biosynthesized from Streptomyces sp. NH21 strain against various bacterial strains

\begin{tabular}{|c|c|c|c|c|c|}
\hline \multirow[t]{3}{*}{ Tested microorganism } & \multicolumn{5}{|c|}{ Survivability $\% \pm(\mathrm{SD})$} \\
\hline & \multicolumn{3}{|l|}{ MIC } & \multicolumn{2}{|l|}{$\mathrm{MBC}$} \\
\hline & 2.5 & 5 & 10 & 140 & 170 \\
\hline Bacillus subtilis ATTC 6633 & - & - & $97 \pm 2.2^{\mathrm{a}}$ & - & $7 \pm 0.40$ \\
\hline Staphylococcus aureus ATTC 6338 & - & $99 \pm 0.68^{\text {n.s. }}$ & - & - & - \\
\hline Klebsiella pneumoniae ATTC 700603 & - & $98 \pm 0.91^{\text {n.s. }}$ & - & - & - \\
\hline Pseudomonas aeruginosa ATTC 10145 & - & - & $81 \pm 1.2^{\mathrm{b}}$ & $5 \pm 0.43$ & - \\
\hline Escherichia coli ATTC 8739 & $98 \pm 0.52$ & - & - & - & - \\
\hline Proteus mirabilis & - & $99 \pm 0.54^{\text {n.s. }}$ & - & - & - \\
\hline Salmonella infantis & - & $94 \pm 0.11^{\text {n.s. }}$ & - & - & - \\
\hline
\end{tabular}

The data is presented as the mean value of three replicates $( \pm \mathrm{SD})$. Within each column means followed by different letter(s) are significantly different $(\mathrm{P}<0.05)$

n.s. not significant $(\mathrm{P}>0.05),-\mathrm{MIC} / \mathrm{MBC}$ not found
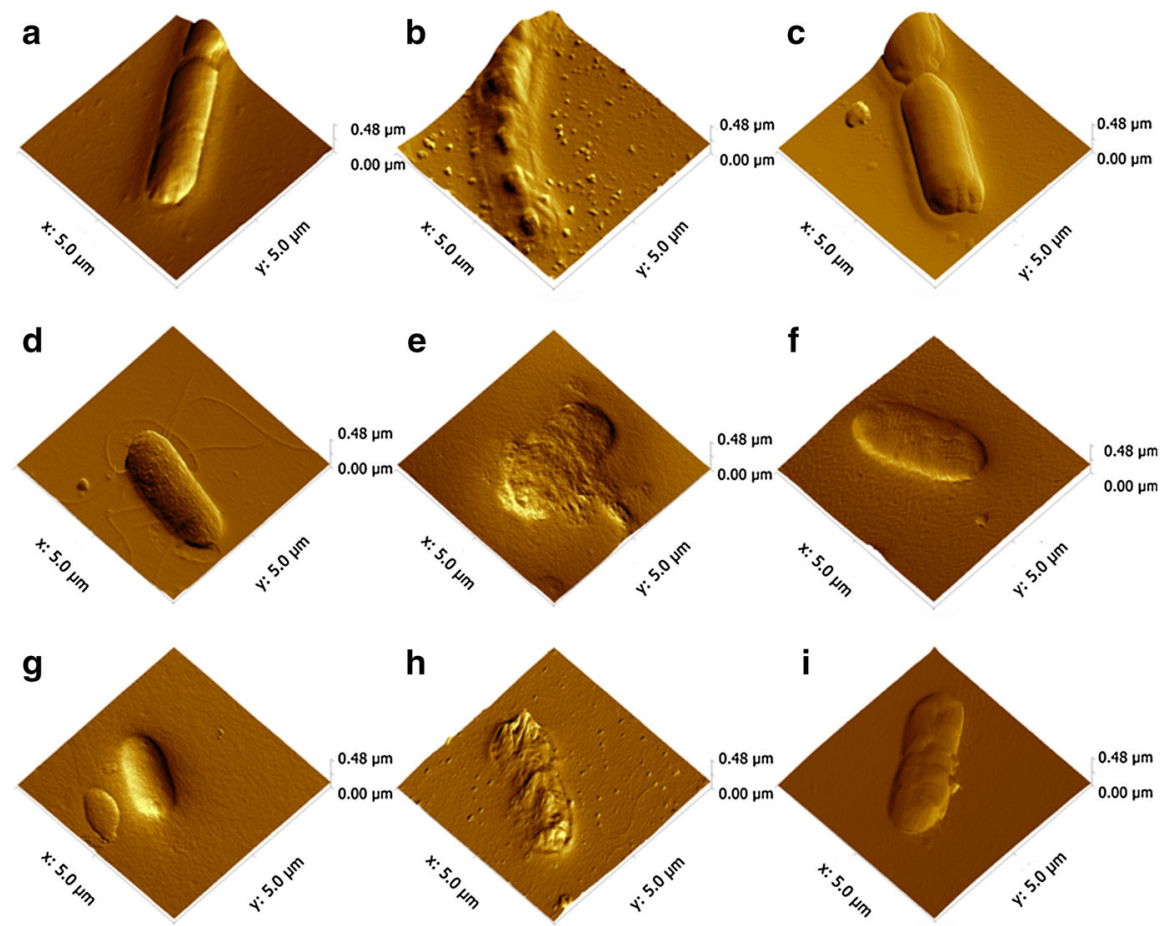

Fig. 9 Atomic force microscopy (AFM) analysis of bacteria after treatment with AgNPs (b, e, h); or AuNPs (c, f, i). Control samples of B. subtilis, E. coli, P. aeruginosa $(\mathbf{a}, \mathbf{d}, \mathbf{g})$, respectively 
24 h showed differences in morphology compared with controls (Fig. 9b, e, h). The E. coli appearing more spherical than rod-like shape. Treated cells had a much rougher surface texture than untreated cells. A destruction of the cell wall, accompanying with spread out of peptidoglycan or outer membrane fragments on the gelatin surface, indicating lysis of the cells. The AuNPs treated bacteria (Fig. 9c, $\mathrm{f}, \mathrm{i})$ showed a lack of visible changes.

\section{Discussion}

Although more than 10,000 microbial active metabolites have been reported to be produced by actinomycetes [37] only few genera such as Thermomonospora, Rhodococcus and Streptomyces have been involved in nanoparticles biosynthesis $[38,39]$. Biogenic synthesis of silver nanoparticles has been well proved by using bacteria, fungi algae and plants [40-42]. Although in recent years functionalized gold nanoparticles have attached much attention their application in biomedicine is still in initial stage.

In the present study, it was found that, Streptomyces sp. strain NH21 have ability to synthesize silver and gold nanoparticles. Moreover, silver nanoparticles were synthesized by culture supernatant and filtrate of starved biomass, which were confirmed in visual observation of color changing from yellow to dark brown. The synthesis of gold nanoparticles was recorded only in supernatant of Streptomyces sp. NH21 strain culture when color of solution changed to purple. The changes in color were observed due to the surface plasmon resonances (SPRs) effect [43, 44] and reduction of $\mathrm{AgNO}_{3}$ or $\mathrm{HAuCl}_{4}$, respectively. The successful synthesis of silver nanoparticles by actinobacteria using culture supernatant and filtrate of starved biomass was confirmed by other authors [45, 46]. Similarly, the actinobacteria mediated synthesis of gold nanoparticles, in few reports, was noticed either in culture supernatant or filtrate of starved biomass [47-49]. The UV-Vis spectra of synthesized nanoparticles showed peaks at 430 and $560 \mathrm{~nm}$, which is specific for silver and gold nanoparticles, respectively $[50,51]$. The absorption peak is related to particle size, which indicates the formation of $\mathrm{Ag}$ and $\mathrm{Au}$ nanoparticles [43, 44]. Metal nanoparticles have free electrons, which give to SPR absorption band, due to the combined vibration of electrons of metal nanoparticles in resonance with the light wave [52]. Further characterization of nanoparticles was carried out by FTIR to find out the biomolecules responsible for the formation and stabilization of the AgNPs and AuNPs. These molecules can bind to nanoparticles through free amine groups in the proteins $[10,53]$. FTIR peaks at $3445 \mathrm{~cm}^{-1}$ can be interpreted as broad O-H stretching, those between 2920 and $2930 \mathrm{~cm}^{-1}$ are probably of C-H stretching vibration, and at $1658 \mathrm{~cm}^{-1}$ can be assigned to $\mathrm{C}=\mathrm{C}$. The peak at $1591 \mathrm{~cm}^{-1}$ can marked as $\mathrm{C}=\mathrm{N}$ stretching vibrations of aromatic amines and prove presence of protein, as well. The absorbance band at $1384 \mathrm{~cm}^{-1}$ is characteristic for amine and amino-methyl stretching groups $[54,55]$. The peak at $1038 \mathrm{~cm}^{-1}$ can be assigned to $\mathrm{C}-\mathrm{O}$ stretching vibration, at $875 \mathrm{~cm}^{-1}$ to $\mathrm{CH}_{3}-$ groups due $\mathrm{CH}_{2}$ rocking vibration. Many researchers have proved the presence of proteins over the metal nanoparticles, that work as a capping agents and are responsible for stabilization of 
nanoparticles [55, 56]. Biosynthesis of gold nanoparticles by Streptomyces isolated from Himalayan Mountain was undertaken for the first time by Balagurunathan et al. [47]. Out of ten actinomycete strains studied, four strains showed intracellular biosynthesis of gold nanoparticles among which Streptomyces viridogens strain HM10 showed high potency. Spherical and rod shaped gold nanoparticles was determinate by TEM and X-ray diffraction analysis. The average particle size was observed in the range of $18-20 \mathrm{~nm}$. The gold nanoparticles were synthesized both intra-and extracellularly [47].

Zeta potential analysis brought information about stability of synthetized nanostructures. It was reported that zeta potential value closer to $-30 \mathrm{mV}$ indicate that metal nanoparticles are more stable $[40,57]$. The analyses of all tested metal nanoparticles revealed the negative values of zeta potential. However it is assumed that synthesized nanoparticles were moderately stable. The negatively charged nanoparticles were found in work by Fayaz et al. [58] and Kupryashina et al. [14]. The authors reported negative zeta potential values of synthesized nanoparticles of -8.5 and $-5.08 \mathrm{mV}$, respectively. Mohanta et al. [59] showed that zeta potential of silver nanoparticles synthesized by Streptomyces sp. was found to be $-17.7 \pm 5.3 \mathrm{mV}$. The difference in zeta potential values of metal nanoparticles, including silver and gold NPs, previously reported by authors may be connected with different conditions of synthesis process and differences between bacteria isolates [14, 57-59].

The NTA and Brownian motion are very fast methods, which allow for estimation of the particle size, size distribution and concentration of nanoparticles. Moreover, these methods are more sensitive than dynamic light scattering (DLS) [2]. Parallel method was also used by Raheman et al. [60] to determine size and size distribution. In the present study, the average size of silver and gold nanoparticles was found to be 45 and $10 \mathrm{~nm}$, respectively. The morphology (shape and size) of synthesized nanoparticles were confirmed by TEM analyses, which revealed that silver and gold nanoparticles were monodispersed and mostly spherical in shape. The size of metal nanoparticles obtained by TEM analysis was consistent with those from NTA. The small sized gold nanoparticles $(10-30 \mathrm{~nm})$ from Streptomyces viridogens was reported by Balagurunathan et al. [47] and silver nanoparticles $(10-40 \mathrm{~nm})$ from $S$. rocheii by Deepa et al. [61].

Microbial synthesis of nanoparticles with different size and shapes depends on the organism involved, concentration of metal ions and duration of metal incubation. For example actinomycete Rhodococcus sp. synthesized gold nanoparticles intracellularly with $5-15 \mathrm{~nm}$ size, whereas another actinomycete Thermomonospora sp. synthesized gold nanoparticles extracellularly with $8 \mathrm{~nm}$ size $[12,38]$.

Zoonoz et al. [48] studied biosynthesis of gold nanoparticles in supernatant of Streptomyces sp. and optimization of synthesis process for enhanced production. To increase nanoparticle synthesis rate the medium optimization was carried out by using different physiochemical conditions such as temperature and incubation time as well as concentration of $\mathrm{HAuCl}_{4}$ used and $\mathrm{pH}$ of medium. Out of set of incubation temperatures used for nanoparticle synthesis, at $30{ }^{\circ} \mathrm{C}$ the highest production of silver nanoparticles was noted. Authors also reported that the highest 
production of gold nanoparticles was observed after $96 \mathrm{~h}$ of incubation, after treatment with $3 \mathrm{mM} \mathrm{HAuCl}{ }_{4}$ and at $\mathrm{pH}$ 6. TEM micrographs showed the average particle size ranged from 10 to $30 \mathrm{~nm}$ at optimized conditions and were spherical in shape. Small sized particles can interact with themselves and form larger particles at nano or micro scale size [48].

There are few reports on gold nanoparticles synthesis by Streptomyces sp. with antibacterial activity. Balagurunathan et al. [47] showed good antibacterial activity of gold nanoparticles against $S$. aureus and E. coli, both approximately $20 \mathrm{~mm}$ zone of inhibition. The antibacterial activity of gold nanoparticles against Gram-positive and Gram-negative bacteria has been reported also by Ramamurthy et al. [62] or Bindhu et al. [63]. Results of those studies presented antibacterial nature of gold nanoparticles but in our studies AuNPs in opposite to AgNPs did not show any antibacterial activity. According to many investigators the gold nanoparticles are mainly know from its potential application in medicine as a drug delivery system or antiviral agent, than as an antibacterial agent Ramamurthy et al. [62].

The antibacterial activity of silver nanoparticles, including chemically as well as biosynthesized once have been well confirmed. Selvakumar and co-workers [64] reported antibacterial potential of silver nanoparticles synthesized from Streptomyces rocheii against B. subtilis, E. coli and $K$. pneumoniae. Similar findings were noticed by Chauhan et al. [65] who used Streptomyces sp. JAR1 for nanoparticle synthesis.

In present studies, silver nanoparticles synthesized from starved biomass of Streptomyces sp. NH21 strain showed higher activity than those from supernatant. Although the MIC value of AgNPs from starved biomass was observed for all tested bacterial strains the MBC of biosynthesized AgNPs was found against $P$. aeruginosa and $B$. subtilis. The various sensitivity of bacteria to silver nanoparticles was observed by other authors [65, 66]. Low MIC values of bioAgNPs from Nocardiopsis sp. MBRC-1 against bacteria was reported by Manivasagan and coworkers [44]. However, silver nanoparticles obtained from Streptomyces sp. strain $\mathrm{NH} 21$ was found to have much higher antibacterial activity than those stydied by Singh and co-workers [67]. Authors reported MIC of AgNPs from Acinetobacter calcoaceticus in the range of $150-600 \mu \mathrm{g} / \mathrm{mL}$ against human pathogenic bacteria. Classification of bacteria as Gram-positive and Gram-negative is based upon their different cell wall structure and composition. Sondi and Salopek-Sondi [18] and Rai et al. [15] claimed that silver nanoparticles attack Gram-negative bacteria by anchoring and penetrating the cell wall, and as a consequence lead to structural changes in the cell membrane causing its increased permeability. Some authors proposed that the antibacterial mechanism of silver nanoparticles is attributable to the formation of free radicals induced membrane damage. Moreover, silver ions released from NPs interact strongly with thiol groups in enzymes and phosphoruscontaining bases. Interaction of AgNPs with DNA may prevent bacterial cell division and DNA replication leading to cell death [4, 68-70].

An atomic force microscopy (AFM) have been used for silver nanoparticles characterization or microorganism observations [65, 71] but visualization of bacterial cells after treatment with biosynthesized nanoparticles by AFM has not been performed. In our studies AFM imaging clearly displayed that AgNPs from 
Streptomyces sp. NH21 strain caused damage of bacterial cells via change in cell morphology. In contrast, AuNPs produced from this strain did not cause damage of bacteria cells.

Activity of nanoparticles on microorganism depends on their size, shape and concentration.

It was proved that smaller nanoparticles are more active against pathogens than bigger ones [72-74]. Van Phu et al. [75] synthesized small nanoparticles in range of 4.3-10 nm and found that concentration and size of AgNPs was mainly responsible for the antibacterial effect along with treatment time. Similar observations were recorded by Martinez-Gutierez et al. [76].

Biosynthesis of silver and gold nanoparticles from actinobacteria is rapid, cheap and simple method to obtain nanoparticles in non-toxic and eco-friendly way. Biosynthesized nanoparticles are small, stable, with antibacterial properties against bacterial pathogens.

Our studies have added a new microbial source for biosynthesis of silver and gold nanoparticles. Further studies are required for exploitation of Streptomyces derived gold nanoparticles and its use in other biotechnological fields.

Acknowledgments This study was supported by Grant "Symphony 1" No. 2013/08/W/NZ8/00701 from The Polish National Science Centre (NCN) and Grants No. 2255-B and 2577-B from Nicolaus Copernicus University.

\section{Compliance with Ethical Standards}

Conflict of interest The authors declare that they have no conflict of interest.

Open Access This article is distributed under the terms of the Creative Commons Attribution 4.0 International License (http://creativecommons.org/licenses/by/4.0/), which permits unrestricted use, distribution, and reproduction in any medium, provided you give appropriate credit to the original author(s) and the source, provide a link to the Creative Commons license, and indicate if changes were made.

\section{References}

1. G. F. Webb, E. M. C. D’Agata, P. Magal, and S. Ruan (2005). Proc. Natl. Acad. Sci. U. S. A. 102, 13343.

2. S. C. Gaikwad, A. P. Ingle, A. K. Gade, M. Rai, A. Falanga, N. Incoronato, L. Russo, S. Galdiero, and M. Galdiero (2013). Int. J. Nanomed. 8, 4303.

3. P. Mukherjee, A. Ahmad, D. Mandal, S. Senapati, S. R. Sainkar, M. I. Khan, R. Parishcha, P. V. Ajaykumar, M. Alam, R. Kumar, and M. Sastry (2001). Nano Lett. 1, 515.

4. F. Okafor, A. Janen, T. Kukhtareva, V. Edwards, and M. Curley (2013). Int. J. Environ. Res. Public Health 10, 5221.

5. P. Golinska, M. Wypij, A. P. Ingle, I. Gupta, H. Dahm, and M. Rai (2014). Appl. Microbiol. Biotechnol. 98, 8083.

6. K. Murugan, G. Benelli, C. Panneerselvam, J. Subramaniam, T. Jeyalalitha, D. Dinesh, M. Nicoletti, J. S. Hwang, U. Suresh, and P. Madhiyazhagan (2015). Exp. Parasitol. 153, 129.

7. R. Rajan, K. Chandran, S. L. Harper, S. IlYun, and P. T. Kalaichelvan (2015). Ind. Crops Prod. 70, 356.

8. G. Benelli (2016). Parasitol. Res. 115, 23. 
9. J. Subramaniam, K. Murugan, C. Panneerselvam, K. Kovendan, P. Madhiyazhagan, D. Dinesh, P. M. Kumar, B. Chandramohan, U. Suresh, R. Rajaganesh, M. S. Alsalhi, S. Devanesan, M. Nicoletti, A. Canale, and G. Benelli (2016). Environ. Sci. Pollut. Res. 23, 1.

10. K. B. Narayanan and N. Sakthivel (2010). Adv. Colloid Interface Sci. 156, 1.

11. N. I. Hulkoti and T. C. Taranath (2014). Colloids Surf B Biointerfaces 121, 474.

12. A. Ahmad, S. Senapati, M. I. Khan, R. Kumar, R. Ramani, V. Srinivas, and M. Sastry (2003). Nanotechnology 14, 824.

13. N. Durán, P. D. Marcato, M. Durán, A. Yadav, A. Gade, and M. Rai (2011). Appl. Microbiol. Biotechnol. 90, 1609.

14. M. A. Kupryashina, E. P. Vetchinkina, A. M. Burov, E. G. Ponomareva, and V. E. Nikitina (2014). Microbiology 82, 833.

15. M. K. Rai, S. D. Deshmukh, A. P. Ingle, and A. K. Gade (2012). J. Appl. Microbiol. 112, 841.

16. X. Li, S. M. Robinson, A. Gupta, K. Saha, Z. Jiang, D. F. Moyano, A. Sahar, M. A. Riley, and V. M. Rotello (2014). ACS Nano 8, 10682.

17. M. A. Gatoo, S. Naseem, M. Y. Arfat, A. M. Dar, K. Qasim, and S. Zubair (2014). Biomed Res. Int. 2014, 498420.

18. I. Sondi and B. Salopek-Sondi (2004). J. Colloid Interface Sci. 275, 177.

19. M. Rai, A. Yadav, and A. Gade (2009). Biotechnol. Adv. 27, 76.

20. D. R. Monteiro, S. Silva, M. Negri, L. F. Gorup, E. R. De Camargo, R. Oliveira, D. B. Barbosa, and M. Henriques (2012). Lett. Appl. Microbiol. 54, 383.

21. K. Murugan, J. S. E. Venus, C. Panneerselvam, S. Bedini, B. Conti, M. Nicoletti, S. K. Sarkar, J. S. Hwang, J. Subramaniam, P. Madhiyazhagan, P. M. Kumar, D. Dinesh, U. Suresh, and G. Benelli (2015). Environ. Sci. Pollut. Res. 22, 17053.

22. D. Dinesh, K. Murugan, P. Madhiyazhagan, C. Panneerselvam, P. Mahesh Kumar, M. Nicoletti, W. Jiang, G. Benelli, B. Chandramohan, and U. Suresh (2015). Parasitol. Res. 114, 1519.

23. E. Navarro, A. Baun, R. Behra, N. B. Hartmann, J. Filser, A.-J. Miao, A. Quigg, P. H. Santschi, and L. Sigg (2008). Ecotoxicology 17, 372.

24. E. D. Cavassin, L. F. P. de Figueiredo, J. P. Otoch, M. M. Seckler, R. A. de Oliveira, F. F. Franco, V. S. Marangoni, V. Zucolotto, A. S. S. Levin, and S. F. Costa (2015). J. Nanobiotechnol. 13, 64.

25. G. Zhao and S. E. Stevens (1998). BioMetals 11, 27.

26. P. C. Chen, S. C. Mwakwari, and A. K. Oyelere (2008). Nanotechnol. Sci. Appl. 1, 45.

27. Y. C. Cao, R. Jin, and C. A. Mirkin (2002). Science 297, 5586.

28. C. Zhu, Q. Zheng, L. Wang, H.-F. Xu, J. Tong, Q. Zhang, Y. Wan, and J. Wu (2015). J. Nanobiotechnol. 13, 1.

29. D. N. Williams, S. H. Ehrman, and T. R. Pulliam Holoman (2006). J. Nanobiotechnol. 4, 3.

30. M. Shah, V. Badwaik, Y. Kherde, H. K. Waghwani, T. Modi, Z. P. Aguilar, H. Rodgers, W. Hamilton, T. Marutharaj, C. Webb, M. B. Lawrenz, and R. Dakshinamurthy (2014). Front. Biosci. 19, 1320.

31. E. Küster and S. T. Williams (1964). Nature 202, 928.

32. D. J. Lane in E. Stackebrandt and M. Goodfellow (eds.), Nucleic Acid Techniques in Bacterial Systematics (Wiley, Chichester, 1991), pp. 115-148.

33. P. Golinska, D. Wang, and M. Goodfellow (2013). Antonie Van Leeuwenhoek 103, 1079.

34. O.-S. Kim, Y.-J. Cho, K. Lee, S.-H. Yoon, M. Kim, H. Na, S.-C. Park, Y. S. Jeon, J.-H. Lee, H. Yi, S. Won, and J. Chun (2012). Int. J. Syst. Evol. Microbiol. 62, 716.

35. R. Louise Meyer, X. Zhou, L. Tang, A. Arpanaei, P. Kingshott, and F. Besenbacher (2010). Ultramicroscopy 110, 1349.

36. D. Nečas and P. Klapetek (2012). Open Phys. 10, 181.

37. J. Bérdy (2005). J. Antibiot. (Tokyo) 58, 1.

38. A. Ahmad, S. Senapati, M. I. Khan, R. Kumar, and M. Sastry (2003). Langmuir 19, 3550.

39. S. Sadhasivam, P. Shanmugam, and K. Yun (2010). Colloids Surf B Biointerfaces 81, 358.

40. A. Gade, A. Ingle, C. Whiteley, and M. Rai (2010). Biotechnol. Lett. 32, 593.

41. R. S. Prakasham, B. S. Kumar, Y. S. Kumar, and K. P. Kumar (2014). Indian J. Microbiol. 54, 329.

42. S. Rajeshkumar and C. Malarkodi (2014). Bioinorg. Chem. Appl. 2014, 1.

43. D. Philip (2008). Spectrochim. Acta Part A Mol. Biomol. Spectrosc. 71, 80.

44. P. Manivasagan, J. Venkatesan, K. Senthilkumar, K. Sivakumar, and S.-K. K. Kim (2013). Biomed Res. Int. 2013, 287638.

45. S. Priyaragini, S. R. Sathishkumar, and K. V. Bhaskararao (2013). Int. J. Pharm. Pharm. Sci. 5, 3. 
46. L. Karthik, G. Kumar, A. V. Kirthi, A. A. Rahuman, and K. V. Bhaskara Rao (2014). Bioprocess Biosyst. Eng. 37, 261.

47. D. Balagurunathan, R. Radhakrishnan, M. Rajendran, and R. B. Velmurugan (2011). Indian J. Biochem. Biophys. 48, 331.

48. N. F. Zonooz, M. Salouti, R. Shapouri, and J. Nasseryan (2012). J. Clust. Sci. $23,375$.

49. S. S. Waghmare, A. M. Deshmukh, and Z. Sadowski (2014). Afr. J. Microbiol. Res. 8, 138.

50. S. Pandey, G. Oza, M. Vishwanathan, and M. Sharon (2012). Ann. Biol. Res. 3, 2378.

51. M. Thenmozhi, K. Kannabiran, R. Kumar, and V. Gopiesh Khanna (2013). J. Med. Mycol 23, 97.

52. M. A. Noginov, G. Zhu, M. Bahoura, J. Adegoke, C. Small, B. A. Ritzo, V. P. Drachev, and V. M. Shalaev (2007). Appl. Phys. B Lasers Opt. 86, 455.

53. F. Ramezani, A. Jebali, and B. Kazemi (2012). Appl. Biochem. Biotechnol. 168, 1549.

54. P. Jeevan, K. Ramya, and A. E. Rena (2012). Indian J. Biotechnol. 11, 72.

55. P. Sivalingam, J. J. Antony, D. Siva, S. Achiraman, and K. Anbarasu (2012). Colloids Surf. B Biointerfaces 98, 12.

56. C. Tamuly, M. Hazarika, S. C. Borah, M. R. Das, and M. P. Boruah (2013). Colloids Surf. B Biointerfaces 102, 627.

57. M. Rai, A. P. Ingle, S. Gaikwad, I. Gupta, A. Gade, and S. Silvério da Silva (2015). J. Appl. Microbiol. 110, 527.

58. A. M. Fayaz, K. Balaji, M. Girilal, R. Yadav, P. T. Kalaichelvan, and R. Venketesan (2010). Nanomedicine 6, 103.

59. Y. K. Mohanta and S. K. Behera (2014). Bioprocess Biosyst. Eng. 37, 2263.

60. F. Raheman, S. Deshmukh, A. Ingle, A. Gade, and M. Rai (2011). Nano Biomed Eng. 3, 174.

61. S. Deepa, K. Kanimozhi, A. Panneerselvam, P. Selvakumar, S. Viveka, S. Prakash, S. Jasminebeaula, and R. Uloganathan (2012). Int. J. Curr. Microbiol. Appl. Sci. 3, 223.

62. C. H. Ramamurthy, M. Padma, I. D. MariyaSamadanam, R. Mareeswaran, A. Suyavaran, M. S. Kumar, K. Premkumar, and C. Thirunavukkarasu (2013). Colloids Surf. B Biointerfaces 102, 808.

63. M. R. Bindhu and M. Umadevi (2014). Mater. Lett. 120, 122.

64. P. Selvakumar, S. Viveka, S. Prakash, S. Jasminebeaula, and R. Uloganathan (2012). Int. J. Pharm. Biol. Sci. 3, 188.

65. R. Chauhan, A. Kumar, and J. Abraham (2013). Sci. Pharm. 81, 607.

66. C. Marambio-Jones and E. M. V. Hoek (2010). J. Nanopart. Res. 12, 1531.

67. R. Singh, P. Wagh, S. Wadhwani, S. Gaidhani, A. Kumbhar, J. Bellare, and B. A. Chopade (2013). Int. J. Nanomed. 8, 4277.

68. J. S. Kim, E. Kuk, K. N. Yu, J. H. Kim, S. J. Park, H. J. Lee, S. H. Kim, Y. K. Park, Y. H. Park, C. Y. Hwang, Y. K. Kim, Y. S. Lee, D. H. Jeong, and M. H. Cho (2007). Nanomed. Nanotechnol. Biol. Med. 3, 95.

69. N. V. Ayala-Núñez, H. H. L. Villegas, L. D. C. I. Turrent, and C. R. Padilla (2009). Nanobiotechnology $\mathbf{5}, 2$.

70. M. Zarei, A. Jamnejad, and E. Khajehali (2014). Jundishapur J. Microbiol. 7, 1.

71. S. C. G. K. Daniel, R. Kumar, V. Sathish, and M. Sivakumar (2011). Int. J. Nanosci. Nanotechnol. 2, 103.

72. C.-N. Lok, C.-M. Ho, R. Chen, Q.-Y. He, W.-Y. Yu, H. Sun, P. K.-H. Tam, J.-F. Chiu, and C.-M. Che (2007). J. Biol. Inorg. Chem. 12, 527.

73. G. A. Martinez-Castanon, N. Niño-Martínez, F. Martínez-Gutierrez, J. R. Martínez-Mendoza, and F. Ruiz (2008). J. Nanopart. Res. 10, 1343.

74. L. Li, J. Sun, X. Li, Y. Zhang, Z. Wang, C. Wang, J. Dai, and Q. Wang (2012). Biomaterials 33, 1714.

75. D. Van Phu, L. A. Quoc, N. N. Duy, N. T. K. Lan, B. D. Du, L. Q. Luan, and N. Q. Hien (2014). Nanoscale Res. Lett. 9, 162.

76. F. Martinez-Gutierrez, P. L. Olive, A. Banuelos, E. Orrantia, N. Nino, E. M. Sanchez, F. Ruiz, H. Bach, and Y. Av-Gay (2010). Nanomed. Nanotechnol. Biol. Med. 6, 681. 